\title{
Occurrence of Coliforms in Water Samples of the Perequê and Penedo Rivers in Paraná, Brazil
}

\author{
Ilma Hiroko Higuti ${ }^{*}$, Ivone Rodrigues Macena ${ }^{2}$, Setuko Masunari ${ }^{3}$, Mario de Oliveira \\ Branco Filho $^{1}$, Marita Maciel Moreira Blaskowiski ${ }^{1}$ and Aguinaldo José do Nascimento ${ }^{2}$. \\ ${ }^{1}$ Departamento de Patologia Básica, ${ }^{2}$ Departamento de Bioquímica, ${ }^{3}$ Departamento de Zoologia, Setor de Ciências \\ Biológicas. Universidade Federal do Paraná, Curitiba, PR, Brazil.
}

\begin{abstract}
The Perequê and Penedo rivers flow through the plains of Praia de Leste and fall into the sea between the municipalities of Pontal do Sul and Ponta do Poço. Both of these rivers belong to the sub-basin of Paranaguá Bay, and are constituent parts of the hydrographic basin of the Atlantic Ocean (State of Paraná). Four sites along the Pereque River (Stations 1-4) and one along the Penedo River (Station 5) were monitorated for water pollution over a 12-month period. During the period of December 1995 to November 1996, three water samples were collected from each site, placed in sterilized bottles and transported to the laboratory in ice-boxes. They were analyzed for the occurrence of total and fecal coliforms, temperature and $\mathrm{pH}$. Fecal pollution was detected throughout the period of study. Coliform contamination was smaller in Station 1 and 5 than in any other sites, probably due to lesser influence from urbanized areas. Water at Station 4 was strongly contaminated due to its close proximity to a sewage canal. This study demonstrated that the Pequerê and Penedo rivers, freshwater shrimps habitats, were heavily contaminated with fecal indicator bacteria, and this occurrence was not related with temperature or $\mathrm{pH}$.
\end{abstract}

Key words: Total coliforms, fecal coliforms, water microbiology.

\section{INTRODUCTION}

Human activities, due to increasing real estate speculation in the coastal region of the State of Paraná, are continuously modifying its complex ecosystem.

The Perequê $\left(25^{\circ} 33^{\prime}-25^{\circ} 49^{\prime} \mathrm{S}\right.$ and $48^{\circ} 20^{\prime}$ $\left.48^{\circ} 30^{\prime} \mathrm{W}\right)$ and Penedo rivers $\left(25^{\circ} 33^{\prime}-25^{\circ} 35^{\prime}\right.$ $\mathrm{S}$ and $48^{\circ} 20^{\prime}-48^{\circ} 23^{\prime} \mathrm{W}$ ) have their sources in the flatlands adjoining Praia de Leste and flow into the sea between the municipalities of Pontal do Sul and the Ponta do Poço, both belonging to the sub-basin of Paranaguá Bay (extension of $607 \mathrm{~km}$ ). Together with other five sub-basins viz. Ribeira, Laranjeiras, Antonina, Nhundiaquara, and Guaratuba Bays, they comprise the hydrographic basin of the Atlantic Ocean in the State of Paraná (Maack, 1968).

The water from those rivers are used, as far as known, only for fishing purposes.
The Perequê River has a total extension of approximately $20 \mathrm{~km}$ and a width varying from 2 to $5 \mathrm{~m}$. No data on its depths are available. The river runs parallel to the coastline for its first $12.5 \mathrm{~km}$; at halfway there are several bends then there is a deviation of almost $90^{\circ}$ to the Southeast, where it has accentuated bends until again taking course parallel to the line of the coast. It then enters into an urbanized area where its course was deviated artificially through a channel that flows into a main channel connecting with the sea. The original course of the river has been constantly modified to adapt to the division of land into lots. At the beginning of the 1990's, its middle portion was interrupted and the waters in its final trajectory now forms a complex marsh that is drained into the sea via the main channel.

The Penedo River has about $6 \mathrm{~km}$ of extension and a variable width from 2 to $8 \mathrm{~m}$. No data on its depths are available. In its initial $1.5 \mathrm{~km}$, it runs Southeast, then deviates about $90^{\circ}$ and runs

\footnotetext{
* Author for correspondence
} 
parallel to the coastline. In its final trajectory, the river forms accentuated bends before draining directly into the sea. A highway over the river indicates direct human influence in the area.

The purpose of this investigation was to determine the distribuition of coliforms along these rivers in order to monitor fecal pollution in this aquatic environment.

\section{MATERIALS AND METHODS}

Sampling location: Four sites along the Perequê river (Station 1-4) and one along the Penedo river (Station 5) were chosen for monitoring water pollution over a 12 month period (Fig. 1).

Sample collection: During the period of December 1995 to November 1996, three water samples of $100 \mathrm{ml}$ each were collected from each site (180 total samples), placed in sterilized bottles and transported to the laboratory in iceboxes at temperatures ranging from 0 to $10^{\circ} \mathrm{C}$. Sample assay: The Multiple Dilution Tube Methods (three tubes) was used to detect the most probable number of total (TC) and fecal coliforms (FC) following the APHA methodology (APHA, 1989). The temperature and $\mathrm{pH}$ of the water were recorded with the use of a Portable pH-mV-Temp Meter (Ingold).

\section{RESULTS AND DISCUSSION}

The criteria for maximum tolerance adopted by the Brazilian Secretariat of Health, Regulation GM/0013/15/jan/1976 for preservation of fishes and other elements of fauna and flora are as follows: fecal coliforms MPN 4000/100 ml, and total colifoms MPN 20,000/100 ml.

The results obtained for the Perequê river (Stations 1-4) and Penedo river (Station 5) are shown in Table I. Taking into account the above Regulation GM/0013/15/jan/1976 for fish culture, fecal pollution was detected throughout the period of study.

Coliform contamination was lower at Stations 1 and 5 than at other stations, probably due to a diminished influence from an urbanized area (Station 1: FC, <300 - 4300 MPN/100 ml; TC, $<300$ - $24000 \mathrm{MPN} / 100 \mathrm{ml}$ (except for the month of November as FC, $4300-24000$ MPN/ $100 \mathrm{ml}$, TC, 4300 - $110000 \mathrm{MPN} / 100 \mathrm{ml}$ ); Station 5: FC, <300 - $4300 \mathrm{MPN} / 100 \mathrm{ml}$; TC, $<300$ - 46000 MPN/100 ml). Samples of Station 4 were strongly contaminated due to its closeness to a sewage canal (FC, $<300$ $>110000$ MPN/100 ml; TC, 9100 - >110000 $\mathrm{MPN} / 100 \mathrm{ml}$ ).

Fecal coliforms are the most commonly employed indicator of fecal contamination in aquatic environments. Various studies on river water have shown the association between fecal indicators and the presence of some fungi (BUCK, 1977, CEBALLOS et al., 1995, HAGLER \& MENDONÇA-HAGLER, 1981) and bacteria (ANTAI, 1987, FULTHORPE et al., 1993, LEE \& CHEN, 1991, OGAN \& NWIIKA, 1993, RINKER et al. 1998, SHEARS et al., 1995, SOKARI et al. 1998, STELZER \& ZIEGERT, 1986). The highly diversified nature of the microbiota reflects a high variety of substrates (APHA, 1989).

The rivers had an annual average temperature of $22.0 \pm 4.6^{\circ} \mathrm{C}$ and $21.1 \pm 4.0^{\circ} \mathrm{C}$, respectively, with $\mathrm{pH} 4.9 \pm 0.6$ (slightly acid) at their surface and bottom.

This study demonstrated that the Pequerê and Penedo rivers, habitats for several species of freshwater shrimps, were heavily contaminated with fecal indicator bacteria, and that the occurrence was not related to temperature or $\mathrm{pH}$. 


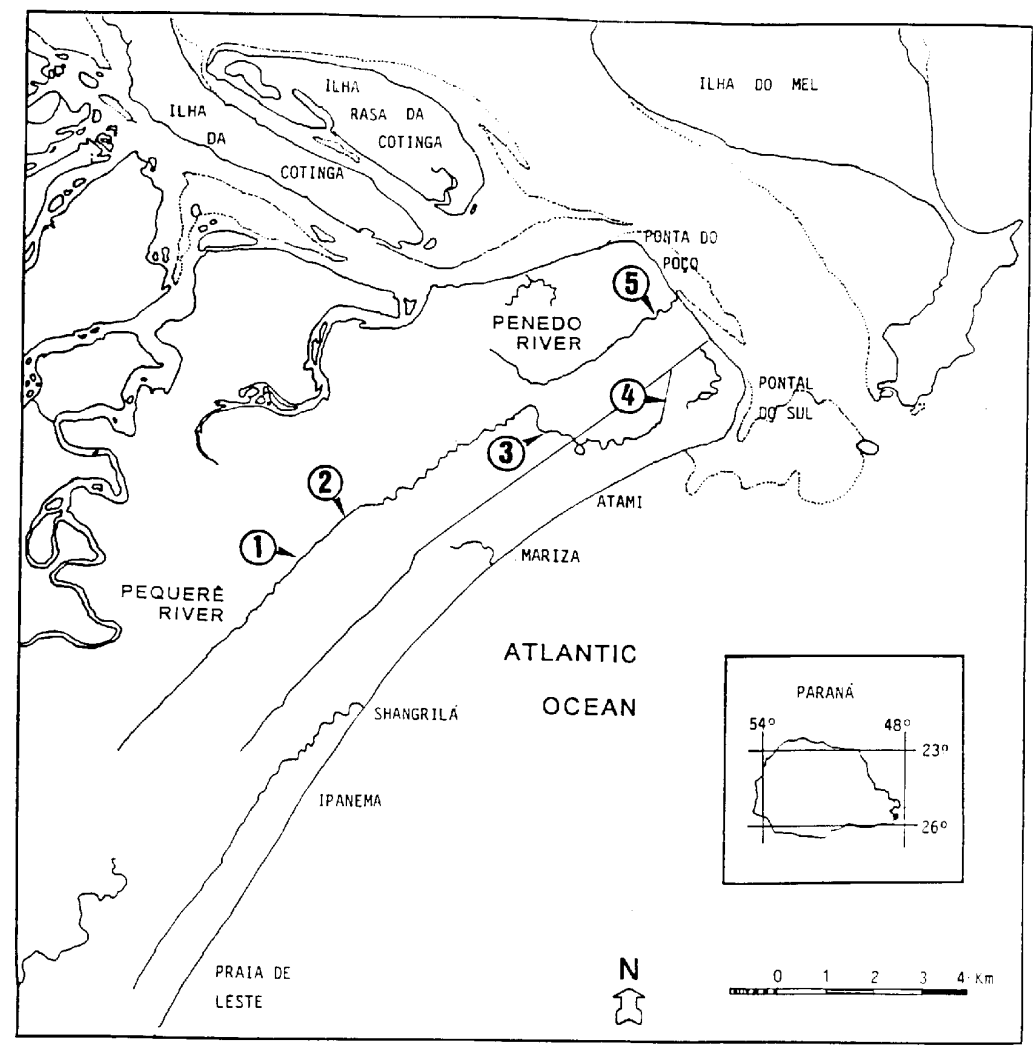

Fig. 1. Map of the coastal land of State of Paraná, indicating the location of the Penedo and Pequerê Rivers (Ministério do Exército - Diretoria do Serviço Geográfico, Page SG 22-X-D-VI-1). The numbers show the collecting sites.

\section{RESUMO}

Os rios Perequê e Penedo têm suas fontes na planície de Praia Leste e fluem para o mar entre os municípios de Pontal do Sul e Ponta do Poço. Ambos pertencem à sub-bacia da Baía de Paranaguá e são partes da bacia hidrográfica do Oceano Atlântico (Estado do Paraná). Foram selecionados quatro sítios ao longo do Rio Perequê (Estações 1-4) e um no Rio Penedo (Estação 5) para monitorar a poluição de água em um período de 12 meses. Durante o período de dezembro de 1995 e novembro de 1996, foram coletadas de cada local, 3 amostras de $100 \mathrm{ml}$ água em frascos esterilizados e transportadas para o laboratório em caixas com gelo. Foram analisadas a ocorrência de coliformes totais (TC) e fecais (FC), temperatura e pH. A contaminação de coliformes foi menor nos sítios 1 e 5 do que em outros locais, provavelmente por causa da menor influência de áreas urbanizadas. A água na estação 4 estava fortemente contaminada por causa de sua proximidade a um canal de esgoto. Este estudo demonstrou que a água dos rios Pequerê e Penedo, "habitats" para várias espécies de camarões de água doce, estão contaminados com coliformes totais e fecais, e esta ocorrência não está relacionada com a temperatura ou $\mathrm{pH}$. 
Table 1. Most Probable Number of Fecal Coliform (FC) and Total Coliforms (TC) per ml of water from the Pequerê and Penedo Rivers

STATION

\begin{tabular}{|c|c|c|c|c|c|c|c|c|c|c|c|c|c|c|c|c|}
\hline \multicolumn{5}{|c|}{1} & \multicolumn{3}{|c|}{2} & & \multicolumn{3}{|c|}{4} & \multicolumn{3}{|c|}{5} \\
\hline M & MolB & 1 & 2 & 3 & 1 & 2 & 3 & 1 & 2 & 3 & 1 & 2 & 3 & 1 & 2 & 2 \\
\hline \multirow[t]{2}{*}{1} & TC & 93 & 43 & 240 & 23 & 93 & 43 & - & & & 39 & 460 & 39 & 43 & 120 & 93 \\
\hline & FC & $<3$ & $<3$ & $<3$ & $<3$ & $<3$ & $<3$ & - & - & & $<3$ & $<3$ & $<3$ & $<3$ & $<3$ & $<3$ \\
\hline \multirow[t]{2}{*}{2} & TC & 23 & 15 & 23 & 93 & $>1100$ & $>1100$ & 43 & 43 & 43 & $>1100$ & 240 & 1100 & $<3$ & 7,3 & 15 \\
\hline & FC & 23 & 3 & 23 & 23 & 9,4 & $<3$ & 3 & $<3$ & $<3$ & $>1100$ & 240 & 240 & $<3$ & $<3$ & $<3$ \\
\hline \multirow[t]{2}{*}{3} & TC & $<3$ & 3,6 & 3,6 & 93 & 43 & 93 & - & - & - & 93 & 43 & 240 & 39 & 240 & 43 \\
\hline & FC & $<3$ & 3,6 & 3,6 & 93 & $<3$ & 23 & - & - & - & 23 & 23 & $<3$ & $<3$ & $<3$ & $<3$ \\
\hline \multirow[t]{2}{*}{4} & TC & 9,1 & 23 & 3,6 & 23 & 23 & 9,1 & 43 & 23 & 93 & 460 & 43 & 93 & 290 & 210 & 75 \\
\hline & FC & $<3$ & $<3$ & $<3$ & $<3$ & $<3$ & $<3$ & 23 & $<$ & 93 & $<3$ & $<3$ & $<3$ & $<3$ & $<3$ & $<3$ \\
\hline \multirow[t]{2}{*}{5} & TC & 3,6 & 3,6 & 9,1 & 9,1 & 9,1 & 3,6 & 21 & 9,1 & 9,1 & 11 & 9,1 & 9,1 & 3,6 & $<3$ & 43 \\
\hline & FC & 3,6 & $<3$ & $<3$ & $<3$ & $<3$ & $<3$ & 9,1 & 9,1 & 9,1 & $<3$ & 9,1 & $<3$ & $<3$ & $<3$ & $<3$ \\
\hline \multirow[t]{2}{*}{6} & TC & 21 & 7,3 & 3,6 & 15 & 75 & 43 & 7,3 & 9,1 & 93 & 21 & 93 & 460 & 43 & 23 & 23 \\
\hline & $\mathrm{FC}$ & 21 & 3,6 & $<3$ & $<3$ & 3 & $<3$ & 7,3 & $<3$ & 6,2 & $<3$ & 23 & $<3$ & 43 & 23 & $<3$ \\
\hline \multirow[t]{2}{*}{7} & TC & 23 & 43 & 150 & 9,1 & 43 & 93 & 43 & 43 & 150 & 460 & 460 & 460 & 7,3 & 9,1 & 23 \\
\hline & FC & 23 & 43 & 39 & $<3$ & 23 & 6,2 & 43 & 2 & 93 & 3 & $<3$ & & 3,6 & 9,1 & $<3$ \\
\hline \multirow[t]{2}{*}{8} & TC & 23 & $<3$ & $<3$ & 28 & 93 & $<3$ & 7,3 & 4. & 9,1 & 1100 & 1100 & 1100 & 23 & 23 & 29 \\
\hline & FC & $<3$ & $<3$ & $<3$ & 28 & 93 & $<3$ & 7,2 & 23 & 9,1 & 1100 & $>1100$ & $>1100$ & 23 & 23 & 9,4 \\
\hline \multirow[t]{2}{*}{9} & $\mathrm{TC}$ & 15 & 43 & 23 & 240 & 23 & 460 & 11 & 15 & 9,1 & $>1100$ & $>1100$ & $>1100$ & 23 & 9,1 & 15 \\
\hline & FC & 9,1 & 23 & $<3$ & $<3$ & $<3$ & 9,4 & $<3$ & 9,1 & $<3$ & $>1100$ & $>1100$ & $>1100$ & $<3$ & 9,1 & 9,1 \\
\hline \multirow[t]{2}{*}{10} & TC & 3,6 & 23 & 23 & 93 & 93 & 93 & 73 & 93 & 75 & 93 & 460 & 460 & $<3$ & $<3$ & 3,6 \\
\hline & FC & 3,6 & 23 & $<3$ & $<3$ & 23 & 23 & 3 & 23 & 75 & 23 & 39 & 460 & $<3$ & $<3$ & $<3$ \\
\hline \multirow[t]{2}{*}{11} & TC & 3,6 & 6,2 & 23 & 7,3 & 23 & 23 & 43 & 7,3 & 15 & 75 & 1100 & 240 & 3,6 & 43 & 3,6 \\
\hline & FC & 3,6 & 6,2 & $<3$ & 7,3 & 23 & 23 & $<3$ & 3,6 & 15 & 75 & 9,4 & 9,4 & $<3$ & $<3$ & $<3$ \\
\hline \multirow[t]{2}{*}{12} & TC & 43 & 240 & 1100 & 1100 & 240 & 460 & - & 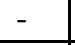 & & 1100 & 1100 & 1100 & 460 & 150 & 1100 \\
\hline & FC & 43 & 240 & 240 & 23 & 23 & $<3$ & - & - & - & 1100 & 240 & 240 & 23 & 9,4 & 1100 \\
\hline
\end{tabular}

M - Month (DEC/95 to NOV/96); Mo - Microorganism; B - Batch; TC - Total coliforms; FC - Fecal coliforms.

The data are expressed in MPN/ml - most probable number by $\mathrm{ml}$ of water.

Perequê River - Station 1- 4; Penedo River - Station 5

\section{REFERENCES}

APHA - American Public Health Association (1989). Standard Methods for the Examination of Water and Wastewater. 17. Ed. New York.

Antai, S.P. (1987). Incidence of Staphylococcus aureus, coliforms and antibiotic-resistant strains of Escherichia coli in rural water supplies in Port Harcourt. J. Appl. Bacteriol. 62, 371-375.

Buck, J.D. (1977). Candida albicans. In: Hoadley, A.W.; Dutka, B.J. (ed.) Bacterial indicators/ Health Hazards Associated with Water. Philadelphia:ASTM, 139-47, (Special Technical Publication 635).
Ceballos, B.S.O.; Lima, E.O.; Konig, A.; Martins, M.T. (1995). Spatial and temporal distribution of fecal coliforms, coliphages, moulds and yeasts in fresh water at the semiarid tropic Northeast region in Brazil (Paraíba State). Rev. Microbiol., 26, 90-100.

Fulthorpe, R.R.; Liss, S.N.; Allen, D.G. (1993). Characterization of bacteria isolated from a bleached kraft pulp mill wastewater treatment system. Can. J. Microbiol., 39, 1324.

Hagler, A.N. \& Mendonça-Hagler, L.C. (1981). Yeast from marine and estuarine waters with different levels of pollution in the state of Rio de Janeiro, Brazil. Appl. Environ. Microbiol., 41, 173-178. 
Lee, W.L. \& Chen, C.P. (1991). Bacteriological quality and the resistance from downstream water source of Kao-Ping river in the period September 1990-January 1991. Kao Hsiung I Hsueh Ko Hsueh Tsa Chih 7, 98-106.

Maack, R. (1968). Geografia física do Estado do Paraná. BDP, UFPR, IBPT. Curitiba, PR Pp. 350.

Ogan, M.T. \& Nwiika, D.E. (1993). Studies on the ecology of aquatic bacteria of the lower Niger Delta: multiple antibiotic resistance among the standard plate count organisms. $J$. Appl. Bacteriol. 74, 595-602.

Rinker, A.G. Jr; Boyd, A.L.; Gary, N.D. \& Kundig, W. (1968). Isolation of multiple antibiotic resistant Enterobacteriaceae from river water. Microbios. 56, 169-75.

Shears, P.; Hussein, M.A.; Chowdhury, A.H. \& Mamun, K.Z. (1995). Water sources and environmental transmission of multiply resistant enteric bacteria in rural Bangladesh. Ann. Trop. Med. Parasitol., 89, 297-303.

Sokari, T.G.; Ibiebele, D.D. \& Ottih, R.M. (1988). Antibiotic resistance among coliforms and Pseudomonas spp. from bodies of water around Port Harcourt, Nigeria. $J$. Appl. Bacteriol. 64, 355-359.

Stelzer, W. \& Ziegert, E. (1986). Occurrence of gentamicin-resistant coliforms in river water samples . Zentralbl. Mikrobiol. 141, 3-9.

Received: June 02, 1998; Revised: June 22, 1998; Accepted: November 13, 1998. 